\title{
Bir Kızamık Salgını Esnasında Kliniğimizce Takip Edilen Erişkin Kızamık Olgularının Değerlendirilmesi
}

\author{
Evaluation of Adult Measles Patients Followed up During an Epidemic
}

\section{Ferit KUŞCƯ ${ }^{1}$, Doğan Barış ÖZTÜRK², Serdar GÜL ${ }^{3}$, Ergenekon KARAGÖZ ${ }^{4}$, Bedia Mutay SUNTUR ${ }^{1}$, Berrin ÜNLÜ ${ }^{1}$, Zehra Doğan TOMUL ${ }^{1}$}

\author{
${ }^{1}$ Adana Numune EAH, Enfeksiyon Hastalıkları ve Klinik Mikrobiyoloji Kliniği, ADANA \\ ${ }^{2}$ Ankara Ulucanlar Göz EAH, Enfeksiyon Hastaliklart ve Klinik Mikrobiyoloji Birimi, ANKARA \\ 3 Kırlkkale Üniversitesi, Enfeksiyon Hastalıkları ve Klinik Mikrobiyoloji A.D., KIRIKKALE \\ ${ }^{4}$ GATA Haydarpaşa Eğitim Hastanesi, Enfeksiyon Hastalıkları ve Klinik Mikrobiyoloji Kliniği, ISTANBUL
}

\begin{abstract}
ÖZET
Kızamık, yüksek bulaşıcılık oranı olan, ateş ve döküntü ile seyreden viral bir enfeksiyon hastalığıdır. Bu çalışmada, OcakNisan 2013 tarihleri arasında kliniğimizde kızamık tanısı ile takip edilen 14 erişkin hastanın irdelenmesi amaçlanmıştır. Klinik bulgu varlığı ile birlikte Enzim Linked Immunosorbent Assay yöntemiyle kızamık IgM pozitifliğinin tespit edilmesiyle tanıları konulan hastaların, retrospektif olarak demografik bilgileri ve klinik semptomları değerlendirilmiştir. Hastaların 10'u kadın $(\% 71,4), 4$ ü $(\% 28,6)$ erkekti. Hastalarda en sık yüksek ateş, halsizlik, öksürük semptomları ile fizik muayenede döküntü, konjonktivit, koplik lekeleri ve tonsillofarenjit bulguları izlenmiştir. Laboratuar bulguları değerlendirildiğinde; hastaların 7 'sinde (\%50) lökopeni, 5 'inde (\%35,7) trombositopeni, 11 'inde $(\% 78,6)$ aspartat aminotransferaz yüksekliği, 6'sinda $(\% 42,9)$ alanin aminotransferaz yüksekliği tespit edildi. Hastaların 11'i kızamık aşı öyküsünü bilmediğini, 3'ü ise hiç kızamık aşısı olmadıklarını belirtti.

Toplumda kızamığa karşı duyarı bireylerin sayısının artması ile kızamık salgınları gözlenebilmektedir. Yüksek bulaşıcılık oranlarına sahip bir hastalık olması nedeniyle, aşılama oranlarının yüksek tutulması hastalığın salgınlara yol açmasını önlemede önemli bir faktör olmaktadır.
\end{abstract}

Anahtar Kelimeler: Kızamık, salgın, klinik

\begin{abstract}
Measles is an highly contagious viral infectious disease which progresses with high fever and rashes. In this study we aimed to evaluate the 14 adult measles patients who had been followed up in our clinic between January-April 2013. The demographic data and the clinical symptoms of the patients whose diagnoses were established with presence of clinical signs and positive anti-measles IgM results with Enzyme Linked Immunosorbent Assay were evaluated retrospectively. Ten of the patients $(71,4 \%)$ were female and 4 of them $(28,6 \%)$ were male. While the most common symptoms were high fever, fatique and cough, most common findings were rash, conjonctivit, Koplic spots and tonsillopharyngitis in the physical examination. According to laboratory results; 7 of the patients $(50 \%)$ had leukopenia, 5 of them $(35,7 \%)$ had trombocytopenia and aspartat aminotransferase levels were elevated in 11 patients $(78,6 \%)$ and alanine aminotransferase levels were elevated in 6 patients $(42,9 \%)$. While 11 of the patients did not remember the history of measles vaccination, 3 of them noted that they had not been vaccinated against measles.

Measles epidemic may emergence in a population with the increasing number of susceptible individuals to the measles. Hence the disease is highly contagious, maintaining the high vaccination rates is an important factor for preventing emergence of epidemics.
\end{abstract}

Keywords: Measles, epidemic, clinical manifestations
KÜ Tıp Fak Derg 2014; 16(3): 12-16

Geliş Tarihi / Received: 22.04.2014

Kabul Tarihi / Accepted: 30.04.2014
Yazışma Adresi / Correspondence: Serdar GÜL

KÜ Tıp Fak, Enfeksiyon Hast. ve Klinik Mikr. A.D., KIRIKKALE

E-mail: serdarguul@ mynet.com Tel: 05059255144 


\section{GíRiș}

Kızamık virusu, Paramyxoviridae ailesinden bir RNA virusudur. Yüksek bulaşıcılık oranı olan kızamık, ateş ve döküntü ile seyreden bir enfeksiyon hastalığıdır (1). Daha önce hastalığa karşı bağışıklığı olmayan kişilerin, virus içeren solunum damlacıklarına maruz kalmaları halinde hastalığa yakalanma riskleri çok yüksektir. Etkili aşılama programları ile hastalığın görülme oranlarının önemli derecede düşürülmesine rağmen, erişkinlerde dönem dönem sporadik vakaların ya da salgınların görülmesi, kızamığın halen önemli bir halk sağlığı problemi olduğunu göstermektedir (2). Bu çalışmada hastanemizde kızamık tanısı ile takip edilen erişkin hastaların verilerinin gözden geçirilmesi amaçlanmıştır.

\section{GEREÇ VE YÖNTEM}

Adana Numune Eğitim ve Araştırma Hastanesi, Enfeksiyon Hastalıkları ve Klinik Mikrobiyoloji polikliniklerine Ocak-Nisan 2013 tarihleri arasında başvuran ve kızamık tanısı alan erişkin hastalar retrospektif olarak incelenmiştir. Kızamık tanısı; Dünya Sağlık Örgütü tarafından belirtilen semptomların varlığı ve birlikteliğinde hastalarda Enzim Linked Immunosorbent Assay (ELISA) ile kızamık IgM pozitifliğinin bulunması ile konulmuştur (3). Hastalar, demografik bilgileri ve laboratuar değerlerinin yer aldığı bir takip formu ile takip edilmiştir. Analiz için SPSS 15,0 paket programı kullanılmıştır.

\section{BULGULAR}

Ocak-Nisan 2013 döneminde, hastanemiz Enfeksiyon Hastalıkları polikliniğine başvuran, kızamıkla uyumlu kliniği olan ve laboratuvar olarak kanitlanan 14 kızamıklı hasta değerlendirmeye alındı. Hastaların 10’u kadın $(\% 71,4), 4$ ü $(\% 28,6)$ erkekti. Yaş aralıkları 1837 arasında değişmekteydi ve yaş ortalaması $26,4 \pm 6,4$ idi. On dört hastanın, 12'si yatırılarak ikisi ise ayaktan takip edildi. Bir hastanın gebelik durumu, bir hastanın Down sendromu, bir hastanın ise talasemisi mevcuttu. Polikliniğimize başvurduklarında semptomların ortalama başlangıç günü $4,6 \pm 1,4$ gün iken, döküntülerinin başlangıç günü ise ortalama $2 \pm 0,9$ idi. Semptom ve bulguların görülme oranları Tablo'1 de gösterilmiştir.

Laboratuvar bulguları değerlendirildiğinde; kan sayımında, hastaların 7'sinde (\%50) lökopeni, 5'inde $(\% 35,7)$ trombositopeni tespit edildi. Biyokimyasal testlerde, $11(\% 78,6)$ hastada aspartat aminotransferaz (AST) yüksekliği, $6(\% 42,9)$ hastada ise alanin aminotransferaz (ALT) yüksekliği vardı. Hastaların hepsinde ELISA ile Kızamık IgM pozitifliği saptandı.

Tablo 1: Hastaların semptom ve bulguları

\begin{tabular}{lc}
\hline Semptomlar & Hasta Sayısı (\%) \\
\hline Yüksek Ateş & $14(\% 100)$ \\
Halsizlik & $14(\% 100)$ \\
Öksürük & $10(\% 71,4)$ \\
Fotofobi & $9(\% 64,3)$ \\
Boğaz Ağrısı & $9(\% 64,3)$ \\
Bulantı-Kusma & $5(\% 35,7)$ \\
\hline Bulgular & $14(\% 100)$ \\
\hline Makülopapüler döküntü & $9(\% 64,3)$ \\
Konjonktivit & $9(\% 64,3)$ \\
Tonsillofarenjit & $9(\% 64,3)$ \\
Koplik lekeleri & \\
Akciğerlerde raller &
\end{tabular}


Hastalığın bulaş yolları sorgulandığında, 2 hastanın çocuklarının, bir hastanın ise kardeşinin kısa süre önce kızamık hastalığı tanısı almış olduğu öğrenildi. Hastaların 11'i daha önce kızamık aşısı yapılıp yapılmadığını bilmezken, 3'ü ise hiç kızamık aşısı olmadıklarını belirtti.

\section{TARTIŞMA}

Kızamık, bulaşıcılığı oldukça yüksek olan, önemli bir viral hastalıktır (4). Aşı öncesi dönemde hastalığın yaş ve cinsiyet ayrımı yapmadığı bilinmektedir (5). Hastalarımız 18-37 yaş arasındaydı ve kadın cinsiyeti ağırlıktaydı. Bizim polikliniğimize yalnızca erişkin hastalar başvurduğundan çocuk hasta izleyemedik. Ankara'da 35 hastanın takip edildiği bir çalışmada da hastaların 25'i kadın hastaydı (1). Ancak kadın cinsiyeti sık görmüş olmamızın nedeni, toplam hasta sayımızın az olması nedeniyle tesadüfü olmuş olabilir.

Hastalarımızın polikliniğe başvurduklarında semptomlarının ortalama başlangıç süresi 4,6 gün; döküntülerinin başlangıç süresi ise ortalama 2 gün bulunurken, Mert ve arkadaşları döküntü öncesi ateş süresini ortalama 4,2 gün olarak tespit etmişlerdir (6).

Hastalarda prodromal dönemde sıkça öksürük, yüksek ateş, halsizlik, öksürük, boğaz ağrısı, fotofobi, bulantıkusma, ishal, myalji gibi semptomlar; hastalık döneminde döküntü, konjonktivit, koplik lekeleri, lenfadenopati, tonsillofaranjit ve akciğerde raller gibi fizik muayene bulguları izlenebilmektedir (1, 3, 6-8). Bizim hastalarımızda da literatürle uygun şekilde en sık yüksek ateş, halsizlik, öksürük semptomları ve döküntü, konjunktivit, koplik lekeleri, tonsillofarenjit gibi fizik muayene bulguları izlenmiştir (Resim 1).

Erişkin kızamık vakalarında laboratuvar bulgularında anormallikler izlenebilir. Lökopeniden birçok çalışmada bahsedilirken (\%11,2-\%73 arası değişen oranlarda) (1,6-8), trombositopeninin gözlendiği çalışmalar da mevcuttur (\%33,6-\%50 oranında) $(6,9)$.
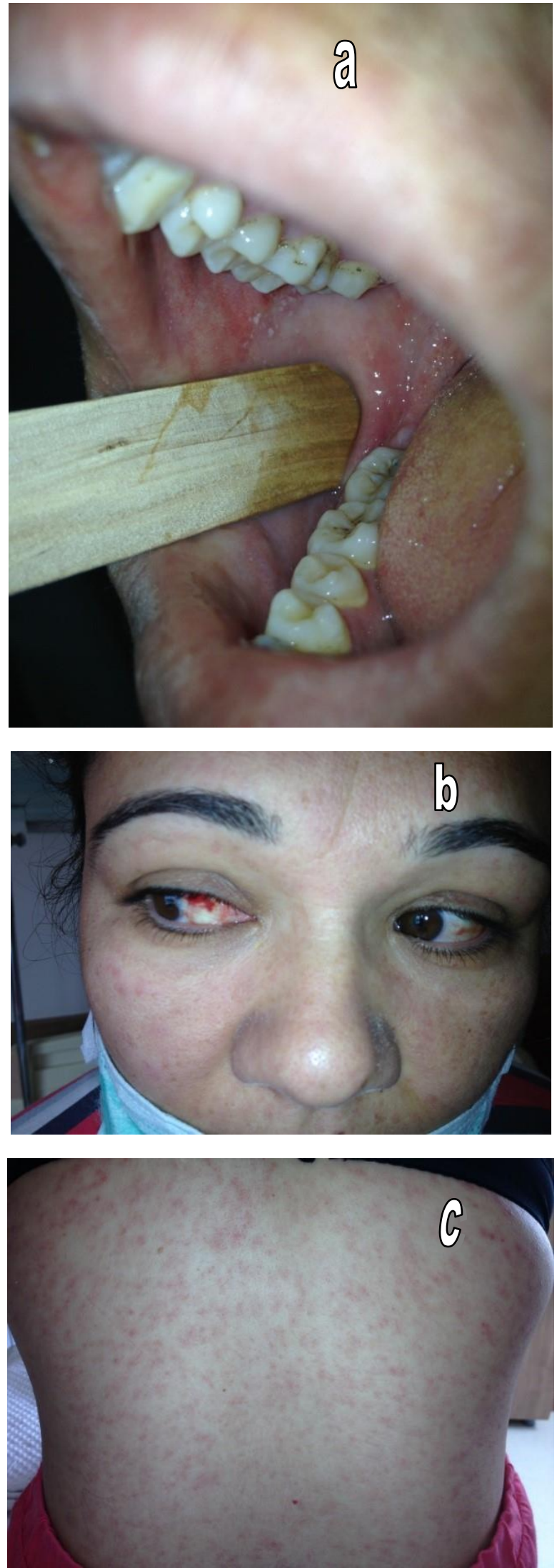

Resim 1. a) Koplik lekeleri b) Konjonktivit c) Sirtta yaygın makülopapüler döküntü 
Bizim çalışmamızda da \%50 oranında lökopeni, \%35,7 oranında trombositopeni izlendi. Karaciğer fonksiyonlarında bozulma da erişkin kızamık olgularında görülebilecek laboratuvar bulgularındandır ve genelde iyi prognozludur (10). Önceki çalışmalarda \%20-80 oranında arasında transaminaz yüksekliği mevcutken $(1,6-8,10)$ bizim hastalarımızın da \%78,6'sında AST yüksekliği, \%42,9'unda ALT yüksekliği izlenmiştir.

Avrupa'da yaşanan 2013 salgını genel olarak değerlendirildiğinde hastaların \%62'si yatırılarak takip edilmiştir ve buna tüm yaş grupları dâhildir (11). Ülkemizde de yalnızca erişkin hasta takip edip \%57 oranında yatırarak takip eden klinikler olduğu gibi (1), hastaların tümünü yatırarak takip eden klinikler de vardır (8). Bizim hastalarımızın da yatış oranı yüksektir $(\% 85,7)$, ancak irdelendiğinde yatış oranı yüksek kliniklerin hastalarının, bizim hastalarımızda da olduğu gibi daha yüksek oranda laboratuar değerleri bozulmuş hastalardan oluştuğu izlenmiştir.

Kızamık aşıyla önlenebilir bir hastalıktır. Eradike edilebilmesi için o toplumun en az \%95'inin hastalığa karşı bağışık olması gerekmektedir. $\mathrm{Bu}$ nedenle kızamık aşılama oranlarının yüksek tutulması hastalığın salgınlara yol açmaması için çok önemlidir (2). Son yıllarda ülkemizde kızamığa karşı yüksek aşılama oranlarına çıkılmasından ve 2006 yılından itibaren Kızamık-Kızamıkçık-Kabakulak aşısının ilk doz aşısını 12.aya değiştirilmesinden sonra çok az kızamık vakası izlenmiştir (12). Ancak geçmiş yıllardaki düşük aşılama oranları veya aşı ile bağışıklığını sağlayamadığımız kişilerin sayısı arttıkça, import bir vakayı takiben aşısız kişilerde kızamık olguları görülmeye başlanabilir. Halk sağlığı uzmanları derneği (HASUDER)'in 12 Mart 2013 tarihli kızamık raporuna göre; Türkiye'de 2012 yılında başlayan kızamık salgını ilk olarak Romanyalı bir aile ve Suudi Arabistan ziyaretinden gelen indeks vakaları takiben olmuştur. Yaş gurupları incelendiğinde en fazla 1 yaş altı daha aşı zamanı gelmemiş bebeklerde izlenirken,
20-29 yaş grubunda, özellikle askerlerde salgın izlenmiştir (2). Bizim hasta grubumuzun da yaşları 1837 arasındaydı ve yaş ortalaması 26,4 idi. 2013 yılında Türkiye'de 7404 kızamık vakası izlenmiştir (11). En çok hangi bölgede hastaların izlenildiğine bakıldığında ise \%81 hastanın, Adana'nın da dâhil olduğu 7 ilde yoğunlaştığı görülmektedir (2). Burada s1k görülmesinin bir nedeninin de özellikle Suriye'deki savaş sonrası artan göç ile aşı durumunu bilmediğimiz insanların topluma dâhil olmasının olabileceğini düşünmekteyiz. Bizim vakalarımızın 11'i aşı olup olmadığını bilmezken, 3 vaka hiç kızamık aşısı olmadığını belirtmekteydi.

Kızamığın yüksek bulaşıcılık oranları nedeniyle, bir toplumda aşı oranlarını yüksek tutmak gerekmektedir. Ancak aşıların \%95 oranında koruyuculuğunun olduğunu da gözden kaçırmamak gerekir. Toplumda belirli oranlarda duyarlı kişi olduğunda kızamık salgınlarının yaşanması beklenmelidir. $\mathrm{Bu}$ yüzden çocukluk aşılamalarındaki mevcut oranları korurken birlikteliğinde genç erişkinlerde aşılama kampanyaları (catch-up) ile toplumdaki bağışıklık oranlarının yükseltilmesi gerekmektedir. Özellikle göç, savaş gibi nedenlerle aşı durumlarının bilinmediği insanların sayısının arttığı durumlarda, bu tedbirlere özellikle dikkat etmek gerekmektedir.

\section{KAYNAKLAR}

1. Celebi G, Pişkin N, Aydemir H, Türkyilmaz R. Evaluation of 35 adult measles cases detected in a measles outbreak. Mikrobiyol Bul. 2007; 41(1):7986.

2. 12 Mart 2013 Kizamık Raporu [Internet] Halk Sağlığı Uzmanları Derneği (HASUDER) Bulaşıcı Hastalıklar Çalışma Grubu [erişim 12 Nisan 2014]. http://hasuder.org.tr/anasayfa/jupgrade/images/hasu der_kızamık_raporu.pdf 
3. Measles [Internet] World Health Organization (WHO) [erişim 12 Nisan 2014]. http://www.who.int/mediacentre/factsheets/fs286/e $\mathrm{n} /$

4. Antona D, Baudon C, Freymuth F, Lamy M, Maine C, Chatelet IPd, et al. La rougeole en France. Médecine/Sciences. 2012; 28: 1003-07.

5. Orenstein W, Strebel P, Papania M, Sutter R, Bellini W, Cochi S. Measles Eradication: Is in Our Future? American Journal of Public Health. 2000; 90(10): 1521-5.

6. Mert A, Özaras R, Tabak F, Bilir M, Mürtezaoğlu A, Öztürk R, Aktuğlu Y. Genç Erişkinlerde Kızamığın Klinik ve Laboratuvar Özellikleri. Flora Dergisi. 2002; 7(4): 272-4.

7. Pahsa A, Özsoy MF, Altunay H, Koçak N, Yıldırım A, Kocabeyoğlu Ö, Çavuşlu Ş, Yenen OŞ. Erişkinlerde Kızamık: 284 Olgunun Retrospektif Değerlendirilmesi. Flora Dergisi. 1999;4(3): 200-5.

8. Dizbay M, Hızel K, Arman D, Şenol E, Aktaş F, Ulutan F. Erişkinde Kızamık: Farklı Klinik Tabloların İrdelenmesi. Klimik Dergisi. 2003; 16: 15-7.
9. Corbin V, Beytout J, Auclair C, Chambon M, Mouly D, Chamoux A, Laurichesse H. Shift of the 2009-2011 measles outbreak from children to adults: an observational review at the University Hospital of Clermont-Ferrand, France. Infection. 2013; 41(6): 1157-61.

10. Satoh A, Kobayashi H, Yoshida T, Tanaka A, Kawajiri T, Oki Y, Kasugai K, Tonai M, Satoh K, Nitta M. Clinicopathological study on liver dysfunction in measles. Intern Med. 1999; 38(5): 454-7.

11. Muscat M, Shefer A, Ben Mamou M, Spataru R, Jankovic D, Deshevoy S, Butler R, Pfeifer D. The state of measles and rubella in the WHO European Region, 2013. Clin Microbiol Infect. 2014; 20(Suppl 5): 12-8.

12. Zencir M. Türkiye'de Kızamık, Kontrollü Artış mı? Salgın mı? [İnternet]. İstanbul: Türk Klinik Mikrobiyoloji ve İnfeksiyon Hastalıkları Derneği [erişim 12 Nisan 2014].

http://www.klimik.org.tr/wpcontent/uploads/2013/10/k\%C4\%B1zam\%C4\%B1k .pdf 